Research Article

\title{
Restoring pollen fertility in transgenic male-sterile eggplant by Cre/loxp-mediated site-specific recombination system
}

\author{
Bihao Cao ${ }^{\mathrm{a}}$, Zhiyin Huang ${ }^{\mathrm{a}}$, Guoju Chen ${ }^{\mathrm{a}}$ and Jianjun Lei \\ College of Horticulture, South China Agriculture University, Guangzhou City, Guanghdong, P.R. China.
}

\begin{abstract}
This study was designed to control plant fertility by cell lethal gene Barnase expressing at specific developmental stage and in specific tissue of male organ under the control of Cre/loxP system, for heterosis breeding, producing hybrid seed of eggplant. The Barnase-coding region was flanked by loxP recognition sites for Cre-recombinase. The eggplant inbred/pure line ('E-38') was transformed with Cre gene and the inbred/pure line ('E-8') was transformed with the Barnase gene situated between loxp. The experiments were done separately, by means of Agrobacterium co-culture. Four $\mathrm{T}_{0}$-plants with the Barnase gene were obtained, all proved to be male-sterile and incapable of producing viable pollen. Flowers stamens were shorter, but the vegetative phenotype was similar to wild-type. Five $\mathrm{T}_{0}$-plants with the Cre gene developed well, blossomed out and set fruit normally. The crossing of male-sterile Barnase-plants with Cre expression transgenic eggplants resulted in site-specific excision with the male-sterile plants producing normal fruits. With the Barnase was excised, pollen fertility was fully restored in the hybrids. The phenotype of these restored plants was the same as that of the wild-type. Thus, the Barnase and Cre genes were capable of stable inheritance and expression in progenies of transgenic plants.
\end{abstract}

Key words: eggplant, male sterility, Barnase gene, Cre gene, Cre/loxP system.

Received: September 8, 2009; Accepted: December 15, 2009.

\section{Introduction}

Eggplant (Solanum melongena L.) is one of the most popular vegetables in Asia and the Mediterranean basin. In these areas, hybrid varieties have been widely grown for many years, because heterosis has significantly enhanced productivity, as well as disease and stress resistance. To obtain hybrid seeds, two inbred lines should be mutually crossed. This procedure, however, is extremely timeconsuming and labor-intensive. In contrast, the utilization of male sterile line is a more efficient way. For this, a suitable restorer system in the male parent is indispensable for acquiring seed-sets, as seeds from $\mathrm{F}_{1}$ hybrids are much sought after for producing economically feasible products. To date, several cytoplasmic male sterility (CMS) systems have been extensively studied in eggplant (Fang et al., 1985; Isshiki and Kawajiri, 2002). However, these could not be successfully applied to the production of hybrid seed and heterosis breeding due to several limitations, such as the instability of male sterility and the absence of agronomically suitable CMS/restorer system.

Genetic engineering offers the opportunity to introduce nuclear male sterility (NMS) into a wide range of

Send correspondence to Bihao Cao. College of Horticulture, South China Agriculture University, Wushan Road in Guangzhou City, 510642 Guanghdong, P.R China. E-mail: caobh01@163.com.

${ }^{a}$ These authors contributed equally to this work. plant species. Various pollination-control mechanisms are based on the genetic engineering of nuclear male sterility and its restoration had been reported and had emerged as tangible options for development of male sterile/restorer lines (Mariani et al., 1990; Rosellini et al., 2001; Jagannath et al., 2001, 2002; Bayer and Hess, 2005). Several strategies have been reported as producing NMS-plants in term of blocking pollen development by tissue-specific transgene expression(Mariani et al., 1990; Cho et al., 2001; Burgess et al., 2002),or altering specific metabolite levels in pollen development, such as sugars (Goetz et al., 2001), jasmonic acid (McConn and Browse, 1996; Stintzi and Browse, 2000) and flavonols (Fischer et al., 1997; Mayer et al., 2001).MS line sterility can be attributed to a newly introduced gene, Barnase, which encodes a special enzyme capable of cleaving RNA molecules in the cells, thereby leading to cell death. This ribonuclease is derived from $\mathrm{Ba}$ cillus amyloliquefaciens (Hartley, 1988). To ensure that only male-flower parts are affected, Barnase should be linked to a special promoter activating the gene only in specific cells responsible for the development of the male flower. As a result, either no pollen or no viable pollen is produced. This strategy had been successfully applied in obtaining male-sterile plants (Denis et al., 1993; Burgess et al., 2002; Luo et al., 2005). To date, most researchers have concentrated on creating RF lines containing a gene for an active substance (Barstar), which neutralizes Barnase 
(Jagannath et al., 2001, 2002; Bisht et al., 2004, 2007), and most crosses of Barnase x Barstar were still male sterile and weak expression of the transgene in vegetative tissues led to yield reduction in Brassica juncea (Jagannath et al., 2002).

Cre/loxP is a site-specific recombination system from phage $P 1$, which was introduced in the 1980s (Sternberg and Hamilton, 1981;Sauer and Henderson, 1988). It is based on the ability of the $P 1$ bacteriophage cyclization recombination $(\mathrm{Cre})$ recombinase gene to affect recombination between pairs of loxp sites, if the lox sites flank a DNA segment in a cis arrangement and are oriented in the same direction $\mathrm{Cre}$ recombinase mediates excision or circularization of the very segment (Dale and Ow, 1990, 1991; Russell et al., 1992).This principle has been utilized to develop different technologies, including marker gene deletion(Gleave et al., 1999; Hoa et al., 2002; Wang et al., 2005) and transgene integration (Srivastava and Ow, 2002). This system can also be used in hybrid breeding programs. Bayer and Hess (2005) succeeded in restoring male fertility by the removal of Barnase via Cre/loxP site-specific recombination in model-plant tobacco.

In this study, a novel method was designed to create an MS line with Barnase and a restore line with Cre/loxP thereby substituting Barstar. Eggplants were transformed with either Cre or Barnase under the control of the tapetum-specific promoter TA29 from tobacco flanked by two identical orientation loxp sites, respectively. The latter(with Barnase) should be male sterile, since tapetum is essential for pollen formation. When crossed, the former (with $\mathrm{Cre}$ ) could cause the latter to lose the Barnase gene in tapetum, whereby $F_{1}$ male viability could be restored, with the subsequent use of the $F_{1}$ hybrid seeds in producing eggplants. In this work we demonstrate tapetum-specific expression of a Barnase transgene causing pollen sterility, and the restoration of male fertility by the same transgene via site-specific recombination using Cre/loxP.

\section{Materials and Methods}

\section{Agrobacterium tumefaciens strain and plasmid}

The expression vector of pCABARTABn and pBINPLUSCre (Figure1) were constructed and transferred into Agrobacterium tumefaciens strain EHA105 by freezethaw method (Song et al., 2004). The pCABARTABn vec- tor contains the Barnase gene under the control of the tapetum-specific promoter TA29 from tobacco, flanked by two identical orientation loxp sites independently, and the Bar gene [conferring phosphinothricin (PPT)-resistance] driven by the CaMV35S promoter from pCABar and the $n p t I I$ gene, both of which serve as plant selection markers. The Barstar gene itself is promoterless. The pBINPLUSCre vector contains Cre driven by a CaMV35S promoter with a 5'- untranslated leader sequence from alfalfa mosaic virus RNA4 (designated as CaMV 35S/AMV an enhancer element from pBI525) and the nptII gene.

\section{Plant materials}

Seeds of the two inbred/pure line eggplant varieties (Solanum melonggena L.) 'E-8' and 'E-38'were provided by the Vegetable Varieties and Genetic Improvement Research Center, South China Agricultural University. After surface sterilization in $70 \%$ ethanol for $50 \mathrm{~s}$, and then in $1.2 \%$ sodium hypochlorite $(20 \% \mathrm{v} / \mathrm{v}$ Clorox Ultra) for $15 \mathrm{~min}$, and rinsing 3 times for $5 \mathrm{~min}$ with sterile water, the seeds were placed on 1/2MS medium with 30 g. $\mathrm{L}^{-1}$ of sucrose and 6.5 g.L. $\mathrm{L}^{-1}$ of agar. Cultures were incubated in the dark until germination (about $5 \mathrm{~d}$ after inoculation), and then kept under a $16 \mathrm{~h} / 8 \mathrm{~h} \mathrm{light} /$ dark period at $25 \pm 0.5^{\circ} \mathrm{C}$. The hypocotyls of 9 11-day-old seedling were excised and used as explants.

\section{Eggplant transformation and plant regeneration}

'E-8'was transformed with the Barnase gene, and 'E-38' with the Cre gene. The explants were dipped for 10 15 min into Agrobacterium tumefaciens solution of an $\mathrm{OD}_{600}$ of 0.5.They were then pre-conditioned on a differentiation medium [MS+6-BA $2.0 \mathrm{mg} . \mathrm{L}^{-1}+$ IAA $0.1 \mathrm{mg} \cdot \mathrm{L}^{-1}$ +ZT $2.0 \mathrm{mg} . \mathrm{L}^{-1}+$ sucrose $\left(30 \mathrm{~g} . \mathrm{L}^{-1}\right)+\operatorname{agar}\left(6.5 \mathrm{~g} . \mathrm{L}^{-1}\right), \mathrm{pH}$ 5.8 ] for 2 days, and co-cultured for $4 \sim 5$ days on differentiation medium. Subsequently, the hypocotyl explants were washed with MS liquid medium containing $500 \mathrm{mg} . \mathrm{L}^{-1}$ cefotaxime, blotted dry and transferred to selection pressure medium $\left[\mathrm{MS}+6-\mathrm{BA}\left(2.0 \mathrm{mg} \cdot \mathrm{L}^{-1}\right)+\mathrm{IAA}\right.$ $\left(0.1 \mathrm{mg} . \mathrm{L}^{-1}\right)+\mathrm{ZT}\left(2.0 \mathrm{mg} \cdot \mathrm{L}^{-1}\right)+\mathrm{PPT}\left(15 \mathrm{mg} . \mathrm{L}^{-1}\right)+\mathrm{Cb}$ $\left(500 \mathrm{mg} . \mathrm{L}^{-1}\right)+30 \mathrm{~g} . \mathrm{L}^{-1}$ sucrose $+6.5 \mathrm{~g} . \mathrm{L}^{-1}$ agar, $\left.\mathrm{pH} 5.8\right]$ in the case of Barnase gene transformation, and another [MS+6-BA $2.0 \mathrm{mg} . \mathrm{L}^{-1}+\mathrm{IAA} 0.1 \mathrm{mg} . \mathrm{L}^{-1}+\mathrm{ZT} 2.0 \mathrm{mg} . \mathrm{L}^{-1}+$ $\mathrm{Km}\left(65 \mathrm{mg} \cdot \mathrm{L}^{-1}\right)+\mathrm{Cb}\left(500 \mathrm{mg} \cdot \mathrm{L}^{-1}\right)+$ sucrose $\left(30 \mathrm{~g} . \mathrm{L}^{-1}\right)+$ $\operatorname{agar}\left(6.5\right.$ g. $\left.\left.\mathrm{L}^{-1}\right), \mathrm{pH} 5.8\right]$ in the case of Cre gene transforma-
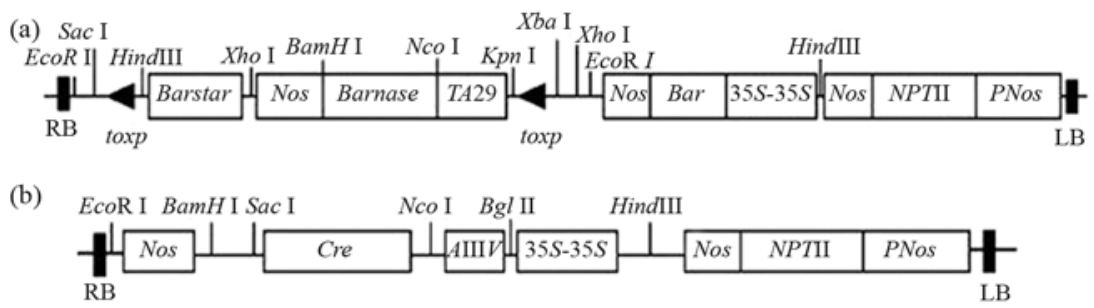

Figure 1 - Sketch map of plant expression vector of Barnase and Cre gene. a: pCABARTABn. b: pBINPLUSCre. 
tion. PPT-resistant and Km-resistant adventitious buds were induced after 25 days. These were cultured on differentiation medium for a $2 \sim 3$ days subculture, to be then excised and transferred to a rooting medium (MS+IAA $\left.0.5 \mathrm{mg} . \mathrm{L}^{-1}+\mathrm{Cb} 200 \mathrm{mg} \cdot \mathrm{L}^{-1}\right)$. About four weeks later, the adventitious buds had already rooted. The plantlets were then transplanted to soil for further analysis.

Transgenic plants were identified by Southern blotting and Northern blotting analysis.

\section{DNA and RNA extraction}

Total genomic DNA was extracted employing CTAB methods (Doyle and Dovle, 1990).

Total RNA was extracted by means of an RNA extraction Trizol Kit (Takara.com).

\section{Polymerase chain reaction}

Total genomic DNA was extracted from the leaves of eggplant (transformed and untransformed) shoots using the CTAB method, and served for Southern blotting. Two pairs of primers for Cre and Barnase gene were designed from their coding region respective. The forward and reverse primer sequences for Barnase were $p B n-1: 5^{\prime}$ GCAGAATTCACCA TGGCACAGGTTATCAAC-3' and $p B n-2: 5$ '-CCCCTCGGATCCGTTATCTGATCTTT GTA-3' respectively; those for Cre were $p C r e-1: 5$ '-GACCATGGCTCCCAAGAAGAAGAGAAA GG TAATGTCCAATTTACTGACCG-3' and $p C r e-2: 5^{\prime}-$ CCCCTCGGATCCGTTATCTGATCTTT GTA-3'; those for Bar were $p$ Bar 1:5'-CCGCTCGAGTCTACCATGAGC CCAGAAC-3' and pBar2 5'-CCGCTCGAGATCAGAT CTCGGTGACG GG-3', and finally those for the deleted fragment were $p$ Barland $p T$ : 5'-AAGGCGATTAAGTTG GGTAACGCC AG-3'.

The PCR reactions were carried out in a $25 \mu \mathrm{L}$ volume containing $2.5 \mu \mathrm{L}$ of a 10 x PCR buffer (Takara),

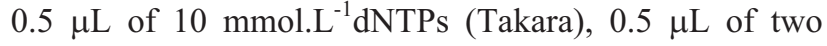
$20 \mu \mathrm{M}$ primer, $0.5 \mu \mathrm{L}$ of $5 \mathrm{U} / \mu \mathrm{L}$ Taq polymerase (Takara), $20 \mu \mathrm{L}$ of distilled $\mathrm{H}_{2} \mathrm{O}$ and $1 \mu \mathrm{L}(20-50 \mathrm{ng})$ of a DNA template. Reactions were carried out in a Peltier thermal cycler (Bio-Rad, USA) as follows: for $\mathrm{Cre}$, one cycle of $5 \mathrm{~min}$ at $94{ }^{\circ} \mathrm{C}$, followed by 30 cycles of $1 \mathrm{~min}$ at $94{ }^{\circ} \mathrm{C}, 1 \mathrm{~min}$ at $55^{\circ} \mathrm{C}, 2 \mathrm{~min}$ at $72{ }^{\circ} \mathrm{C}$, and one final cycle of $10 \mathrm{~min}$ at $72{ }^{\circ} \mathrm{C}$; for Barnase, one cycle of $3 \mathrm{~min}$ at $94{ }^{\circ} \mathrm{C}$, followed by 30 cycles of $1 \mathrm{~min}$ at $94{ }^{\circ} \mathrm{C}, 1 \mathrm{~min}$ at $52{ }^{\circ} \mathrm{C}, 2 \mathrm{~min}$ at $72{ }^{\circ} \mathrm{C}$, and one final cycle of $10 \mathrm{~min}$ at $72{ }^{\circ} \mathrm{C}$; for Bar and the deleted fragment, one cycle of $5 \mathrm{~min}$ at $94^{\circ} \mathrm{C}$, followed by 35 cycles of $1 \mathrm{~min}$ at $94{ }^{\circ} \mathrm{C}, 1 \mathrm{~min}$ at $56^{\circ} \mathrm{C}, 2 \mathrm{~min}$ at $72{ }^{\circ} \mathrm{C}$, and one final cycle of $10 \mathrm{~min}$ at $72{ }^{\circ} \mathrm{C}$. The products were stored at $4{ }^{\circ} \mathrm{C}$, and separated in $1.2 \%$ agarose with an electrophoresis systems (Bio-Rad,sub-cell model 192, USA). Bands were recorded using the Chemi Doc system (Bio-Rad, USA).

\section{Southern blot analysis}

Genomic DNA of the transformants $\left(\mathrm{T}_{0}\right)$ and untransformed control plants were digested with EcoR [The digestion reaction was carried out in a $10 \mu \mathrm{L}$ volume containing $2 \mu \mathrm{g}$ of DNA (about $2 \mu \mathrm{L}$ ), $2 \mu \mathrm{L}$ of a $10 \mathrm{x}$ buffer, $2 \mu \mathrm{L}$ of EcoR and $4 \mu \mathrm{L}$ of $\mathrm{ddH}_{2} \mathrm{O}$ at $37^{\circ} \mathrm{C}$ for 10 to $12 \mathrm{~h}$ ]. Southern blot analysis was carried out using $15 \mu \mathrm{g}$ of genomic DNA. The digested genomic DNA was separated on a $0.8 \%$ agarose gel and transferred to positively charged nylon membranes according to manufacturer's instructions (Boehringer Mannheim Com). The Barnase and Cre gene fragment labeled with (DIG) dCTP by using random labeling (Boehringer Mannheim Com), were used as probes. Hybridization was carried out by DNA labeling and a Detection Kit (Boehringer Mannheim Com.), the nylon membranes being washed with $2 \times$ SSC, $0.1 \%$ SDS; $1 \times$ SSC, $0.1 \% \mathrm{SDS} ; 0.5 \times \mathrm{SSC}$ and $0.1 \% \mathrm{SDS}$ at $65^{\circ} \mathrm{C}$ for $15 \mathrm{~min}$ respectively.

\section{Northern blot analysis}

Hybridization was carried out by DNA labeling and a Detection Kit (Boehringer Mannheim Com.). Approximately $12 \mu \mathrm{g}$ of the total RNA was run on a $1.2 \%$ denaturing agarose gel containing formaldehyde and then transferred onto positively charged nylon membrane (Boehringer Mannheim Com). The DIG-labeled Barnase and $\mathrm{Cre}$ gene fragment were used as probes.

\section{Floral organ morphology and pollen viability testing}

The difference between transgenic and non-transgenic plants, especially as regards floral organ morphology, was carefully checked. Pollen grains, collected between 8 and 9 a.m. were stored in a Petri dishes, which were then placed in a refrigerator. On initiating the experiment, one drop of the freshly prepared medium was placed on a cover slip, and small quantities of pollen grains dispersed therein. The cover slip was then mounted on a cavity slide and the margins of the cover slip were smeared with wax. After ten hours the preparations were microscopically examined. More than a hundred pollen grains per germination were observed and the percentage of germination was calculated on the basis of these observations. The culture medium was $1.0 \%$ sucrose supplemented with $1.0 \%$ boric acid, $5 \mathrm{mg} . \mathrm{L}^{-1}$ $\mathrm{GA}_{3}$ and $1.0 \%$ agar. The hanging drop method was then applied in experiments, with exception of those where sugaragar constituted the culture medium base.

Pollen vigor was tested by the TTC staining method, whereby pollen was placed into a $1 \%$ TTC solution for $30 \mathrm{~min}$ for microscopic examination.

\section{Pollination}

Unopened flower buds about 3-4 $\mathrm{cm}$ in length were sliced open lengthwise and emasculated with forceps. Mature pollen from the donor plant was transferred by brush- 
ing anthers onto the stigmas of emasculated plants. Pollinated flowers were labeled and bagged with small plastic bags to prevent uncontrolled cross-pollination. Self-pollination was achieved by covering intact flowers with small plastic bags prior to opening.

\section{Analysis of seed germination frequency and segregation ratios}

Backcrossed $T_{1}$ seeds from individual $T_{0}$ plants were surface-sterilized and germinated on non-selective media according to the procedures described above. Seed germination frequency for each progeny plant was calculated as the percentage of seeds germinated versus seeds inoculated. The apices of seedlings were excised and placed onto an MS medium with the appropriate selective pressure (15 mg. $\mathrm{L}^{-1} \mathrm{PPT}$ ). Rooting and survival of plantlets were recorded. Segregation ratios were calculated in terms of resistance/sensitivity $(\mathrm{R} / \mathrm{s})$ to the selective agent and subsequently correlated with the male sterility/fertility phenotype when the $T_{1}$ plants came to flowering. Segregation data for each event was subjected to statistical analysis $\left(\chi^{2}\right.$ test at $95 \%$ confidence limit) to determine fitness.

\section{Analysis of heterosis of $F_{1}$ crossing of transgenic male sterile plants with Cre-expressing transgenic plants}

The $\mathrm{F}_{1}$ crosses of transgenic male-sterile plants with Cre-expressing transgenic plants, 'E-8', 'E-38'and $\mathrm{F}_{1}$ ('E-8' x 'E-38') were transplanted to greenhouse. Plants growth, fruit, seeds and yield were all analyzed.

\section{Results}

\section{Regeneration and detection of transgenic plants}

Most of the explants were incapable of differentiating, and turned yellow, although some $\mathrm{Km}^{\mathrm{r}}$ and $\mathrm{PPT}^{\mathrm{r}}$ ad-

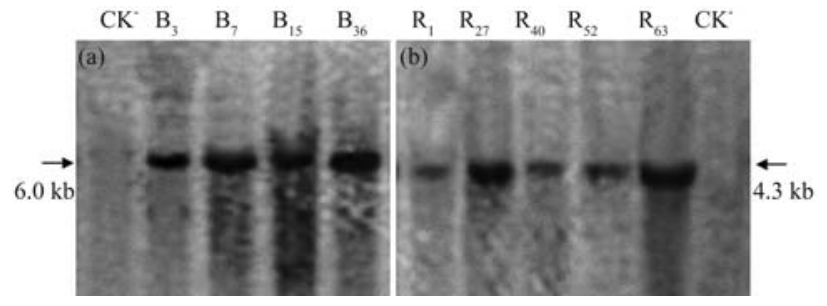

Figure 2 - Southern-blot analysis of transgenic plants. (a) Southern blot of Barnase transgenic plants; CK- showing a non-transgenic plant (E-8); $\mathrm{B}_{3}$, $\mathrm{B}_{7}, \mathrm{~B}_{15}, \mathrm{~B}_{36}$ showing Barnase transgenic plants; (b) Southern blot of Cre transgenic plants; $\mathrm{CK}^{-}$showing a non-transgenic plant (E-38); $\mathrm{R}_{1}, \mathrm{R}_{27}, \mathrm{R}_{40}$, $\mathrm{R}_{52}, \mathrm{R}_{63}$ showing Cre transgenic plants.

ventitious bud rosettes were differentiated from the cut end of hypocotyl explants after 25 days of culture on a selective medium. Five Kan-resistant buds and four PPT- resistant buds were finally obtained at last, the Barnase transgenic plants $\left(\mathrm{B}_{3}, \mathrm{~B}_{7}, \mathrm{~B}_{15}, \mathrm{~B}_{36}\right)$ and the Cre transgenic plants $\left(\mathrm{R}_{1}\right.$, $\mathrm{R}_{27}, \mathrm{R}_{40}, \mathrm{R}_{52}, \mathrm{R}_{63}$ ) being screened out by Southern blotting (Figure 2). The results demonstrated that $\mathrm{Cre}$ and Barnase genes had been integrated into the genome of the respective transgenic lines, the target gene being all single copy in the transgenic plants. These transgenic plants were propagated. After shoot rooting had been induced on the rooting medium, these were then transplanted into vermiculite. The transgenic and nontransgenic plants were detected by Northern blotting. The transgenic plant $\mathrm{R}_{63}$ and $\mathrm{B}_{3}$ were chosen randomly for analyzing Cre and Barnase gene expression in the different parts of the plant. The results showed that the Cre gene was expressed in the flower, stem, leaf and root of the transgenic plant $\mathrm{R}_{63}$, but not in those of the non-transgenic plant (Figure 3a), whereas Barnase gene was only expressed in inflorescence of the transgenic plant $B_{3}$, but not in the root, stem and leaf of $B_{3}$, and with no expression whatsoever in the non-transgenic plants (Figure 3b). In order to analyze the expression level of Cre and Barnse gene among different transgenic plants,
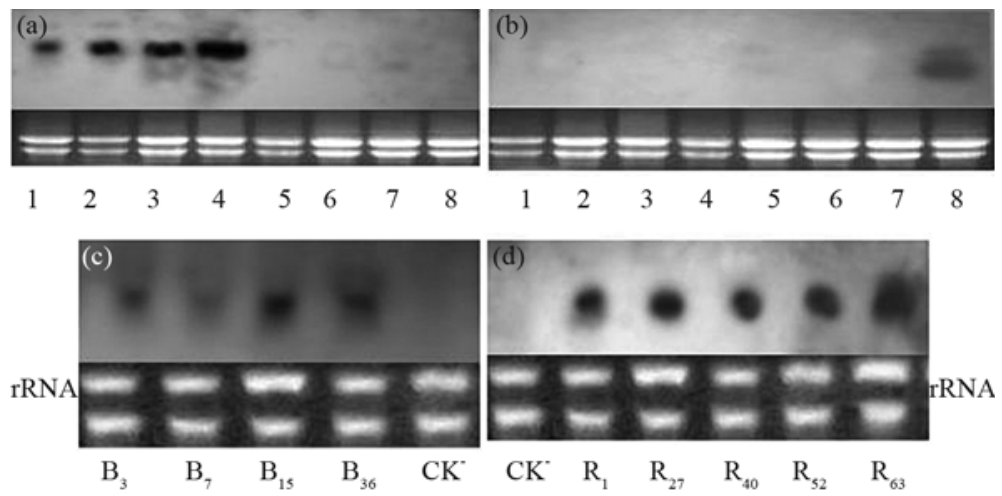

Figure 3 - Northern blotting analysis of transgenic plants. (a) Cre gene expression in different parts of transgenic and non-transgenic plants; lanes 1-4 showing the flower, stem, leaf and root of a transgenic plant $\left(\mathrm{R}_{63}\right)$; lanes 5-8 showing the flower, stem, leaf and root of a non-transgenic plant(E-38). (b) Barnase gene expression in different parts of transgenic and non-transgenic plants; lanes 1-4 showing the root, stem, leaf and flower of a non-transgenic plant (E-8); lanes 5-8 showing the root, stem, leaf and flower of a transgenic plant ( $\mathrm{B}_{3}$ ); (c) Barnase gene expression in the flower of four different transgenic plants $\left(\mathrm{B}_{3}, \mathrm{~B}_{7}, \mathrm{~B}_{15}\right.$ and $\left.\mathrm{B}_{36}\right)$; $\mathrm{CK}^{-}$: a non-transgenic plant (E-8); (d) Cre gene expression in the leaf of five different transgenic plants $\left(\mathrm{R}_{1}, \mathrm{R}_{27}, \mathrm{R}_{40}, \mathrm{R}_{52}\right.$ and $\left.\mathrm{R}_{63}\right) ; \mathrm{CK}^{-}$: a non-transgenic plant (E-38). 
all the four transgenic lines with the Barnase gene and five transgenic lines with the Cre gene were identified by Northern blotting, the results demonstrating that expression levels were different in various transgenic plants (Figure $3 \mathrm{c}, \mathrm{d})$. These results showed that the target genes were expressed in transgenic plants, but not in non-transgenic plants, although Cre gene expression was established, and expression the Barnase gene occurred only in the inflorescence of the transgenic plants.

\section{Floral organ morphology and pollen vigor of transgenic plants}

Compared with CK plants, the transgenic plants with Barnase gene showed no morphological differences in leaves, shape or height except for the inflorescences in greenhouse culture. Transgenic plants either produced no pollens or only a small amount of non-viable pollens incapable of germinating, thereby indicating male- sterility. In contrast to the red pollen of the wild-type, pollen grains from male-sterile plants displayed a grayish color by TTC testing (Figure 4). The staminal length of male-sterile plant was shorter than that of wild-type, while the anthers of the male-sterile plants were shrunken (Figure 5).

Compared with the wild-type, the phenotypes of all the five transgenic $\mathrm{T}_{0}$-plants with the $\mathrm{Cre}$ gene showed normal phenotypes and were self-pollinated so as to produce homozygous progenies.

\section{Crossing of male-sterile transgenic with non-transgenic plants}

Four male-sterile $\mathrm{T}_{0}$ plants $\left(\mathrm{B}_{3}, \mathrm{~B}_{7}, \mathrm{~B}_{15}\right.$ and $\left.\mathrm{B}_{36}\right)$, when crossed with wild-type plants ('E- 8 ', CK) were capable of

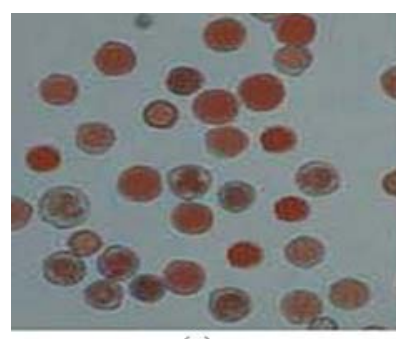

(a)

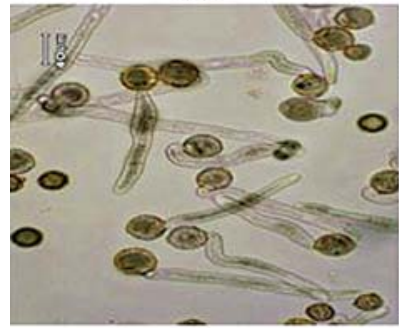

(c)

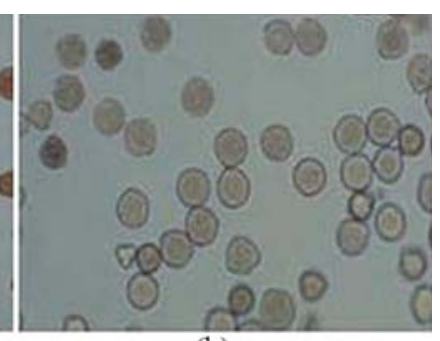

(b)

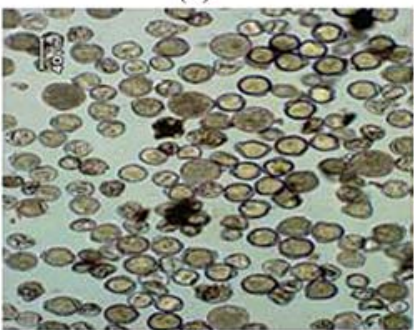

(d)
Figure 4 - Testing the viability of pollen from a Barnase transgenic plant $\left(\mathrm{B}_{3}\right)$ and a non-transgenic plant. (a) TTC testing of pollen from a nontransgenic plant (E-8). (b) TTC testing of pollen from a Barnase gene transgenic plant $\left(\mathrm{B}_{3}\right)$. (c) showing the germination of pollen from a nontransgenic plant (E-8). (d) showing the germination of pollen from a Barnase gene transgenic plant $\left(\mathrm{B}_{3}\right)$.
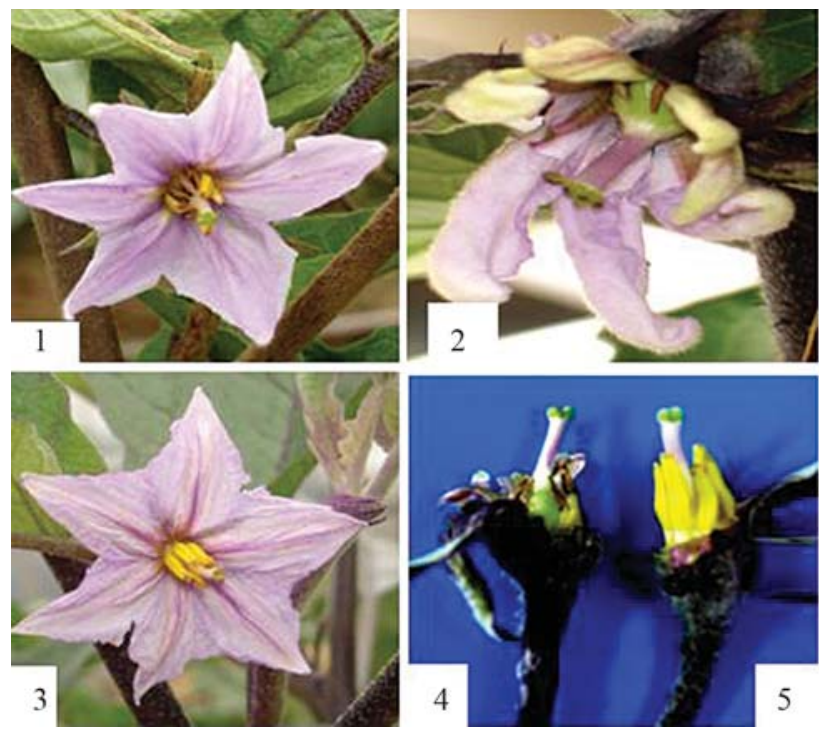

Figure 5 - Stigmata, anthers and flowers of a Barnase transgenic plant and a non-transgenic plant. Panel1 showing the flower of a transgenic MS plant $\left(\mathrm{B}_{7}\right), 2$ and 4 the flower of a transgenic MS plant $\left(\mathrm{B}_{3}\right)$, and 3 and 5 showing the flower of a non-transgenic plant (E-8).

producing normal fruit with normal seeds. In $\mathrm{PPT}^{\mathrm{r}}$ and $\mathrm{PPT}^{\mathrm{s}}$ plants, the ratio in the progeny showed 1:1, after spraying greenhouse seedlings with 1 2 leaves, two or three times with $15 \mathrm{mg} . \mathrm{L}^{-1}$ PPT (Table 1).The PPT ${ }^{\mathrm{r}}$ plants in the progenies showed male sterility and could not produce fruits after self-pollination. About 50\% plants in progenies were fertile. The progeny plants were identified by PCR using Barnase gene primers (Figure 6), and the results revealing that all the male-sterile plants contained the Barnase gene, whereas fertile ones did not. From these results, it is possible to deduce that the Barnase gene could be stably inherited and expressed in the progeny of transgenic plants. At the same time, if transgenic male sterile plants are used to produce $\mathrm{F}_{1}$ seed in the future, $100 \%$ male-sterile lines may be obtained by spraying PPT to eliminate fertile plants.

When $T_{0}$ transgenic plants with Cre gene $\left(\mathrm{R}_{1}, \mathrm{R}_{27}\right.$, $\mathrm{R}_{40}, \mathrm{R}_{52}, \mathrm{R}_{63}$ ) were self-pollinated, they could produce normal fruit with normal seeds. The progenies of $\mathrm{R}_{63}$ from self-pollination were randomly chosen for analyzing $\mathrm{Cre}$ gene inheritance. The result showed that 99 plants were

Table 1 - Segregation profiles among $T_{1}$ progenies of transgenic plants crossed with nontransgenic plants E-8

\begin{tabular}{lcccc}
\hline $\begin{array}{l}\text { Transgenic } \\
\text { line }\end{array}$ & $\begin{array}{c}\text { Number of } \\
\text { seeding on } \\
\text { selection }\end{array}$ & $\begin{array}{c}\text { Number of } \\
\text { PPT-resistant } \\
\text { plants }\end{array}$ & $\begin{array}{c}\text { Number of } \\
\text { PPT-susceptible } \\
\text { plant }\end{array}$ & $\chi_{0.05}^{2}=3.84$ \\
\hline $\mathrm{B}_{3-1}$ & 90 & 47 & 43 & 0.1 \\
$\mathrm{~B}_{7-1}$ & 110 & 54 & 56 & 0.01 \\
$\mathrm{~B}_{15-1}$ & 95 & 49 & 46 & 0.04 \\
$\mathrm{~B}_{36-1}$ & 100 & 52 & 48 & 0.09 \\
\hline
\end{tabular}




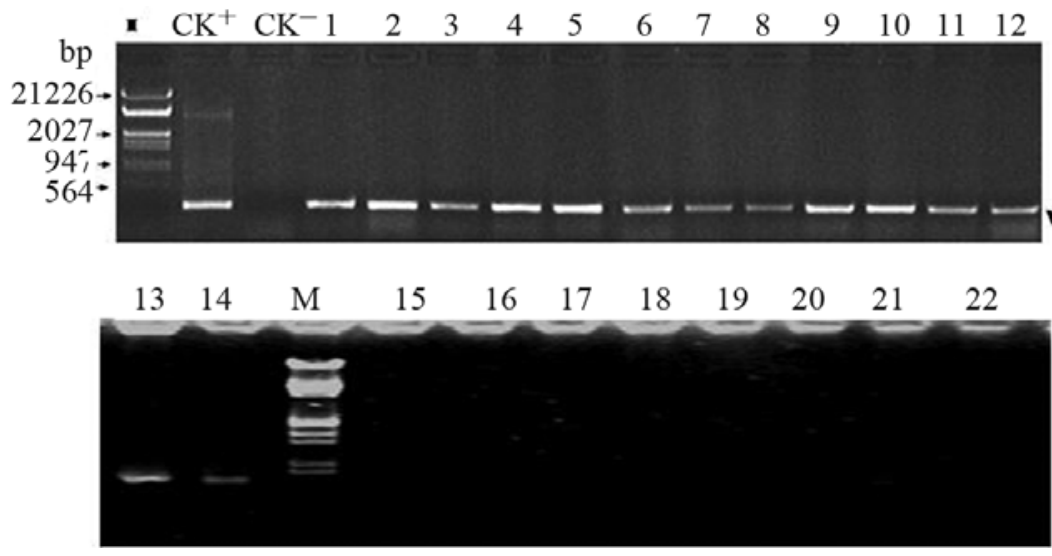

Figure 6 - PCR detection of Barnase-related MS and male-fertile plants in the progeny of a Barnase transgenic plant $\left(\mathrm{B}_{3}\right)$ crossed with a non-transgenic (E-8). M: Marker; lane 1 showing positive CK (pCABARTABn); lanes 2-14 showing male-sterile plants among progenies of $\mathrm{B}_{3} \times \mathrm{E}-8$; lanes 15-22 showing male fertile plants among progenies of $\mathrm{B}_{3} \mathrm{x}$ E-8.

Kan-resistant, 36 plants were Kan-susceptible among $135 \mathrm{~T}_{1}$ plants of $\mathrm{R}_{63}$ with a $\mathrm{R}: \mathrm{S}$ ration of $3: 1\left(\chi^{2}=0.12<\right.$ $\left.\chi_{0.05}^{2}=3.84\right)$.

\section{Crossing of male-sterile with Cre-expressing plants restored fertility in hybrids}

The Barnase gene was flanked by loxP sites in the same orientation (Figure 1). Thus, Cre -mediated recombination should lead to Barnase excision, whereby the crossing of male-sterile plants with $\mathrm{Cre}$-expressing plants would give rise to fertile progeny. Four Barnase-expression lines $\left(\mathrm{B}_{3}, \mathrm{~B}_{7}, \mathrm{~B}_{15}\right.$ and $\left.\mathrm{B}_{36}\right)$ were crossed with $\mathrm{R}_{63}$, and $\mathrm{B}_{7}$ were crossed with $R_{27}, 60$ plants from each combination being transferred to the field. All the $\mathrm{F}_{1}$-plants were fully selffertile, thus capable of producing normal fruits (Figure 7), besides displaying the same phenotype and flower morphology as wild $\mathrm{F}_{1}$-plants ('E-8' x 'E-38',nontransgenic plant). $F_{1}$-plants of two combinations $\left(B_{3} \times R_{63}\right.$ and $B_{7} \times$ $R_{27}$ ) used to analyze the heterosis, showed this phenomenon in plant height, fruit length and weight, when compare to 'E-8' and 'E-38' (Table 2), thereby indicating that transgenic male-sterile plants and $\mathrm{Cre}$-expressing plants may be applied to future eggplant-heterosis breeding.

Thirty $\mathrm{F}_{1}$-plants surviving kanamycin and PPT selection from each of five crosses were randomly chosen for further analysis. Barnase, Bar and Cre gene were analyzed in early flower buds by PCR. The result showed that, apart from the impossibility amplifying Barnase gene, Cre and Bar gene bands were present in the flower of $\mathrm{F}_{1}$-plants (Figure 8; Table 3). At the same time in all $30 \mathrm{~F}_{1}$-plants from $\mathrm{B}_{3}$ $\mathrm{x} \mathrm{R}_{63}$ detected by Southern blotting using a Barnase gene fragment as probe, there were no signs of hybridization (Figure 9). The recombination residue fragment was analyzed deeply by PCR. The expected fragment should be about $2.3 \mathrm{~kb}$ before recombination and about $1.3 \mathrm{~kb}$ fragment should be deleted after recombination and a fragment of about $1.0 \mathrm{~kb}$ could be residual in $\mathrm{F}_{1}$ plants distributed dif-

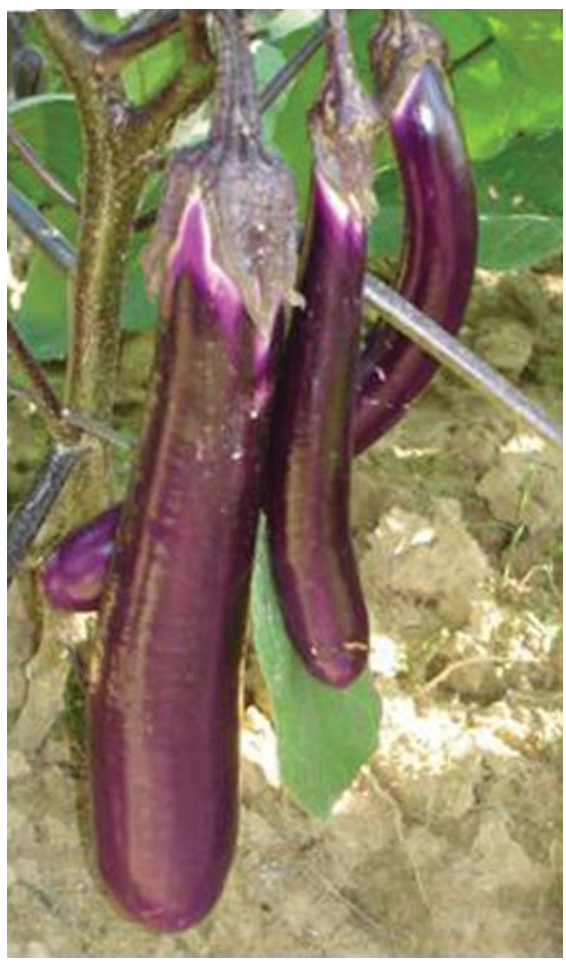

Figure 7 - Fruit in $F_{1}$ of a cross between a male-sterility plant $\left(B_{3}\right)$ and a Cre-expressing plant $\left(\mathrm{R}_{63}\right)$.

ferently between transgenic male -sterile plants and transgenic Cre plants (Figure 10). Thus the transgenic malesterile plant $\left(\mathrm{B}_{3}\right)$, three $\mathrm{F}_{1}$ plants without the Barnase gene $\left(\mathrm{B}_{3} \times \mathrm{R}_{63}\right)$ and the $\mathrm{pCABARTABn}$ expression vector, were identified though PCR, the results showing that about $2.3 \mathrm{~kb}$ of the band had been amplified in the $\mathrm{B}_{3}$ plants and pCABARTABn (positive control), whereas only the $1.0 \mathrm{~kb}$ residual fragment was only amplified in $\mathrm{F}_{1}$ plant (Figure 11). PCR products and Southern blotting results confirmed the site-specific nature of recombination and the excision of the Barnase gene. 
Table 2 - Comparison of heterosis in hybrid combination with that of other varieties.

\begin{tabular}{lcccc}
\hline Material & Plant height $(\mathrm{cm})$ & Per fruit weight $(\mathrm{g})$ & Fruit length $(\mathrm{cm})$ & Total Yield $(\mathrm{kg})$ \\
\hline E-8 $\left(\mathrm{CK}_{1}\right)$ & $86.3 \pm 4.29 \mathrm{~b}$ & $195.6 \pm 5.42 \mathrm{~b}$ & $23.7 \pm 1.18 \mathrm{~b}$ & $13.6 \pm 1.23 \mathrm{~b}$ \\
E-38 $\left(\mathrm{CK}_{2}\right)$ & $90.7 \pm 3.16 \mathrm{~b}$ & $207.4 \pm 4.33 \mathrm{~b}$ & $25.3 \pm 1.65 \mathrm{~b}$ & $15.7 \pm 1.35 \mathrm{~b}$ \\
E-8 $\times$ E-38(CK $)$ & $120.8 \pm 3.13 \mathrm{a}$ & $245.5 \pm 4.21 \mathrm{a}$ & $30.8 \pm 1.35 \mathrm{a}$ & $25.4 \pm 1.62 \mathrm{a}$ \\
$\mathrm{B}_{3} \times \mathrm{R}_{63}$ & $123.5 \pm 3.02 \mathrm{a}$ & $243.6 \pm 3.87 \mathrm{a}$ & $30.5 \pm 1.52 \mathrm{a}$ & $25.7 \pm 1.27 \mathrm{a}$ \\
$\mathrm{B}_{7} \times \mathrm{R}_{27}$ & $122.6 \pm 3.34 \mathrm{a}$ & $242.8 \pm 4.05 \mathrm{a}$ & $30.3 \pm 1.63 \mathrm{a}$ & $24.8 \pm 2.06 \mathrm{a}$ \\
\hline
\end{tabular}

Table 3 - PCR analysis of Barnase x Cre progenies.

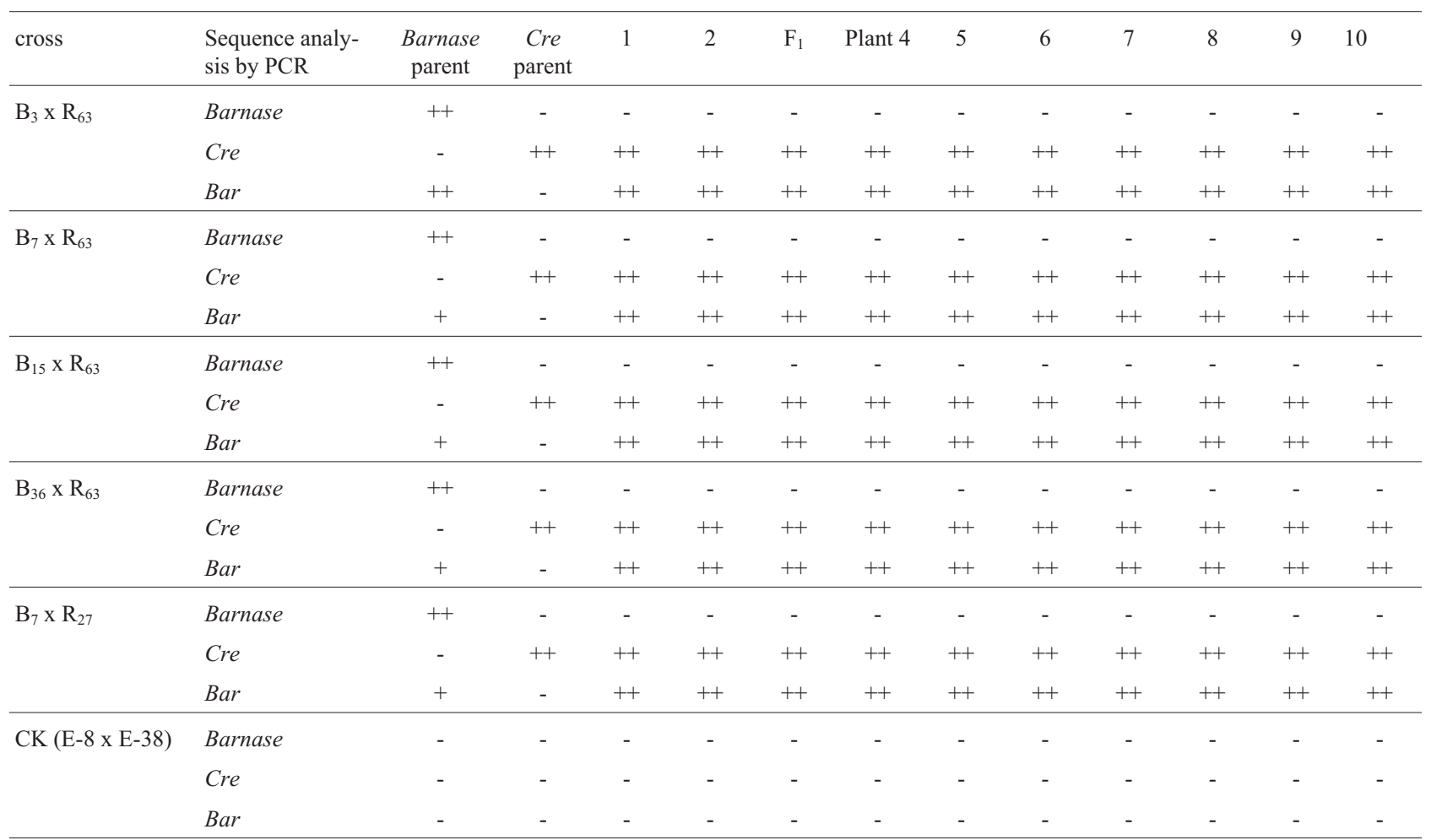

Ck; notransgenic plant; + showing presence; - showing absence.

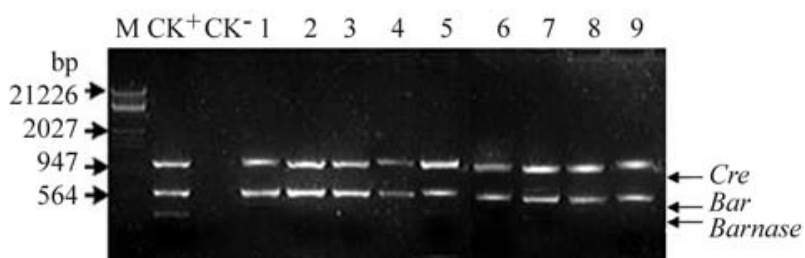

Figure 8 - PCR detection of progenies of Barnase, Bar and Cre in progenies of transgenic plant crossings. M: Markers; $\mathrm{Ck}^{+}$: showing positive $\mathrm{CK}$ (pCABARTABn + pBINPLUSCre); $\mathrm{CK}^{-}$showing a non-transgenic plant (E-8 x E-38); Lanes 1-9 showing a $F_{1}$ plant from crossing a transgenic male-sterile plant $\left(\mathrm{B}_{3}\right)$ and a transgenic plant with Cre gene $\left(\mathrm{R}_{63}\right)$.

\section{Discussion}

Up to now there have been many reports on the male sterility of eggplant (Jasmin, 1954; Fang et al., 1985;

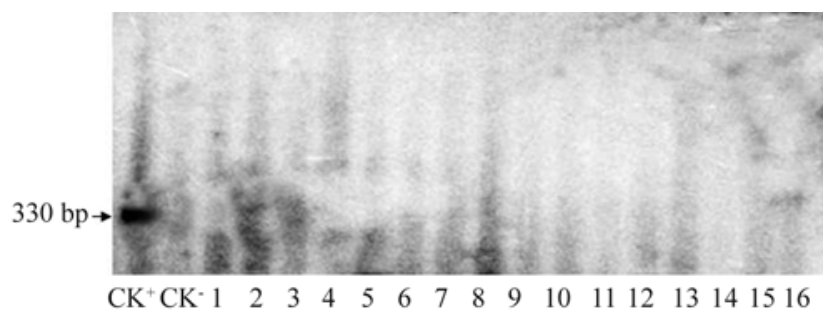

Figure 9 - Southern blotting for Barnase gene detection in $\mathrm{F}_{1}$ of a crossing between a male-sterile plant $\left(\mathrm{B}_{3}\right)$ and a Cre-expressing plant $\left(\mathrm{R}_{63}\right)$. Lane $\mathrm{Ck}+$ showing positive $\mathrm{CK}$ (Barnase gene PCR product); lane $\mathrm{CK}^{-}$showing a non-transgenic plant (E-8 x E-38); lanes 1-16 showing $\mathrm{F}_{1}$ progeny from the crossing of a transgenic male-sterile plant $\left(\mathrm{B}_{3}\right)$ and a Cre transgenic plant $\left(\mathrm{R}_{63}\right)$.

Phatak and Jaworski, 1989; Phatak et al., 1991; Isshiki and Kawajiri, 2002; Tian et al., 2004). Even so, there is the lack 


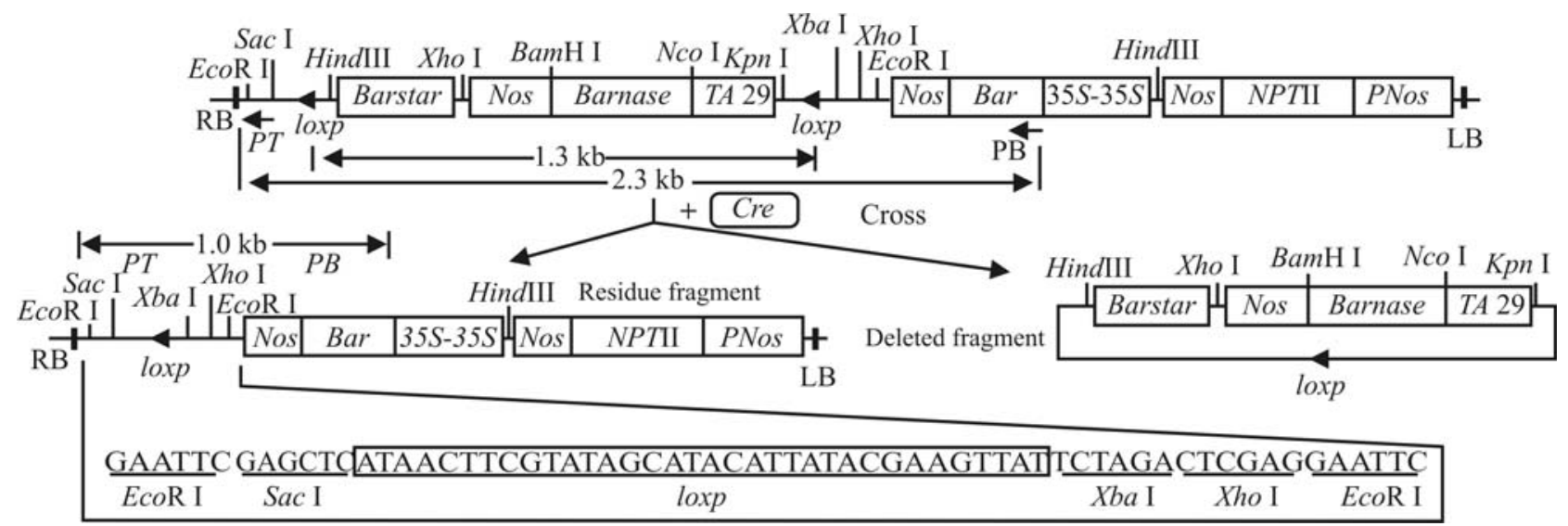

Figure 10 - Sequence structure and site characteristics before and after Cre-mediated recombination.

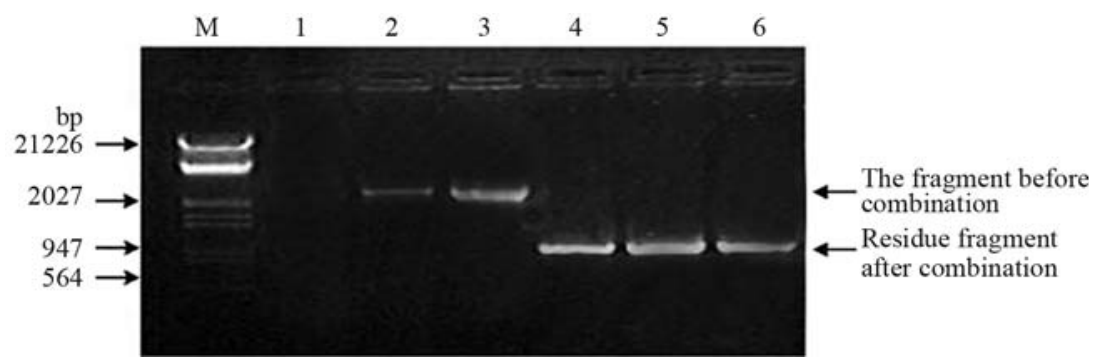

Figure 11 - PCR analysis of the change in fragment size after recombination. $\mathrm{M}: \lambda \mathrm{DNA} / \mathrm{EcoRV}+$ Hind marker; lanes lane 1 showing negative control $\left(\mathrm{F}_{1}\right.$ of E-8 x E-38, non-transgenic plant); lane2 showing pCABARTABn; lane 3 showing a transgenic male-sterile plant (B ${ }_{3}$ ); lanes 4-6 showing sterile gene-deleted $F_{1}$ plants $\left(B_{3} \times R_{63}\right)$.

of an appropriate male-sterile line for heterosis breeding and the production of $F_{1}$ seeds. Genetic engineering may offer a new opportunity to introduce nuclear male sterility (NMS) to eggplant.

Previous studies of Cre-mediated recombination in plants focused on the removal of selectable marker genes or the production of transgenic plants for single copies of marker genes (Dale and Ow, 1991; Bayley et al., 1992; Srivastava et al., 1999; Hoa et al., 2002). Tapetum- specific expression of a Barnase transgene was used to introduce male sterility, as was shown earlier by Mariani et al. (1990). In the this study, we demonstrated that the use of the Cre/loxP-system is another trait of considerable impact in plant breeding, restoring transgenic pollen fertility. The transgenic $\mathrm{T}_{0}$-plants showed the expected male-sterile phenotype. Reciprocal cross between transgenic and nontransgenic, $\mathrm{T}_{0}$-plants clearly demonstrated male-sterility without affecting female fertility, and stable inheritance of the phenotype. Co-segregation of Barnase and Bar gene provided an easy way to obtain male-sterile plants by crossing with wild-type plants via PPT selection in progeny. A transgenic line with constitutive Cre expression served as fertility restorer. The absence of phenotypic differences in Cre-homozygous plants when compared with the wildtype, supports earlier reports to this effect in transgenic tobacco (Odell and Russel, 1994; Ow and Medburry, 1995).
In contrast it was observed that high-level expression of Cre may affect growth in transgenic tomato, petunia, and tobacco (Que et al., 1998; Coppoolse et al., 2003).The Barnase-coding region was flanked by a loxP site Cre-mediated site-specific recombination restored fertility in the hybrids by excision of Barnase and all progenies showed male fertility, thus demonstrating the high efficiency of the system. The one hundred percent efficiency of Cre in the excision of single-copy marker genes has also been reported by Gleave et al. (1999). although in other studies recombination efficiencies were no than 45\% (Bayley et al. 1992) or about 50\% (Dale and Ow, 1991).

Luo et al. (2000) used the FLP/frt site-specific recombination system for restoring fertility in Arabidopsis thaliana transgenic plants. They observed $100 \%$ recombination efficiency in parents with a single copy of the frtflanked transgene per haploid genome, thereby infering that this occurs irrespective of the recombinase used. Luo et al. (2000) postulated that alterations in recombination sites, such as DNA methylation, possibly hinder the binding of the recombinase protein to its target site. In other systems using transgenes, such as Barnase/Barstar, crop loss due to partial sterility cannot be ruled out. In Brassica juncea, most of the Barnase-Barstar crosses were still male-sterile and weak expression of the transgene in vegetative tissues resulted in yield reduction (Jagannath et al., 2002). In our 
system we detected no phenotypic effects other than those implied in fully restoring pollen fertility. Thus, the use of the Cre/loxP site-specific recombination system, as demonstrated with model plant tobacco (Bayer and Hess, 2005), appears to be the most promising in hybrid breeding programs with agronomically important crop plants.

\section{References}

Bayer M and Hess D (2005)Restoring full pollen fertility in transgenic male-sterile tobacco (Nicotiana tabacum L.) by Cremediated site-specific recombination. Mol Breed 15:193203.

Bayley CC, Morgan M, Dale EC and Ow DW (1992).Exchange of gene activity in transgenic plants catalyzed by the Cre-lox site-specific recombination system. Plant Mol Biol 18:353-361.

Bisht NC, Jagannath A, Gupta V, Burma PK and Pental D (2004) A two gene-two promoter system for enhanced expression of a restorer gene (barstar) and development of improved fertility restorer lines for hybrid seed production in crop plants. Mol Breed 14:129-144.

Bisht NC, Jagannath A, Burma PK, Pradhan AK and Pental D (2007) Retransformation of a male sterile barnase line with the barstar gene as an efficient alternative method to identify male sterile-restorer combinations for heterosis breeding. Plant Cell Rep 26:727-733.

Burgess DG, Ralston EJ, Hanson WG, Heckert M, Ho M, Jenq T, Palys JM, Tang K and Gutterson N (2002) A novel, two-component system for cell lethality and its use in engineering nuclear male-sterility in plants. Plant J 31:113-125.

Cho HJ, Kim S, Kim M and Kim BD (2001) Production of transgenic male sterile tobacco plants with the cDNA encoding a ribosome inactivating protein in Dianthus sinensis L. Mol Cell 11:326-333.

Coppoolse ER, de Vroomen MJ, Roelofs D, Smit J, van Gennip F, Hersmus BJM, Nijkamp HJJ and van Haren MJJ (2003) Cre recombinase expression can result in phenotypic aberrations in plants. Plant Mol Biol 51:263-279.

Dale EC and Ow DW (1990) Intra- and inter site-specific recombination in plant cells mediated by bacteriophage P1 recombinase. Gene 91:79-85.

Dale EC and Ow DW (1991) Gene transfer with subsequent removal of the selection gene from the host genome. Proc Natl Acad Sci USA 88:10558-10562.

Denis M, Delourme R, Gourret JP, Mariani C and Renard M (1993) Expression of engineered nuclear male sterility in Brassica napus (genetics, morphology, cytology, and sensitivity to temperature). Plant Physiol 101:1295-1304.

Doyle JJ and Doyle JL (1990) Isolation of plant DNA from fresh tissue. Focus 12:12-14.

Fang MR, Mao RC and Xie WH (1985) Breeding cytoplasmically male sterile lines of eggplant. Acta Hort Sinica 12:261-266.

Fischer R, Budde I and Hain R (1997) Stilbene synthase gene expression causes changes in flower colour and male sterility in tobacco. Plant J 11:489-498.

Gleave AP, Mitra DS, Mudge SR and Morris BAM (1999) Selectable marker-free transgenic plants without sexual crossing: Transient expression of cre recombinase and use of a conditional lethal dominant gene. Plant Mol Biol 40:223-235.
Goetz M, Godt DE, Guivarc'h A, Kahmann U, Chriqui D and Roitsch T(2001) Induction of male sterility in plants by metabolic engineering of the carbohydrate supply. Proc Natl Acad Sci USA 98:6522-6527.

Hartley RW (1988) Barnase and barstar, expression of its cloned inhibitor permits expression of a cloned ribonuclease. J Mol Biol 202:913-915.

Hoa TTC, Bong BB, Huq E and Hodges TK (2002) Cre/lox site-specific recombination controls the excision of a transgene from the rice genome. Theor Appl Genet 104:518-525.

Isshiki S and Kawajiri N (2002)Effect of cytoplasm of Solanum violaceum Ort. on fertility of eggplants (Solanum melongena L.). Sci Hort 93:9-18.

Jagannath A, Bandyopadhyay P, Arumugam N, Gupta V, Burma PK and Pental D (2001) The use of a spacer DNA fragment insulates the tissue-specific expression of a cytotoxic gene (barnase) and allows high-frequency generation of transgenic male sterile lines in Brassica juncea L. Mol Breed 8:11-23.

Jagannath A, Arumugam N, Gupta V, Pradhan AK, Burma PK and Pental D (2002) Development of transgenic barstar lines and identification of a male sterile (barnase)/restorer (barstar) combination for heterosis breeding in Indian oilseed mustard (Brassica juncea). Curr Sci 82:46-52.

Jasmin JJ (1954) Male sterility in Solanum melongena L.: Preliminary report on a functional type of male seterility in eggplants. Proc Am Soc Hort Sci 63:443.

Luo H, Lyznik LA, Gidoni D and Hodges TK (2000) FLPmediated recombination for use in hybrid plant production. Plant J 3:423-430.

Luo H, Kausch AP, Hu Q, Nelson K, Wipff JK, Fricker CCR, Owen TP, Moreno MA, Lee J-Y and Hodges TK (2005) Controlling transgene escape in GM creeping bentgrass. Mol Breed 16:185-188.

Mariani C, De Beuckeleer M,Truettner J, Leemans J and Goldberg RB (1990) Induction of male sterility in plants by a chimeric ribonuclease gene. Nature 347:737-741.

Mayer MJ, Narbad A, Parr AJ, Parker ML, Walton NJ and Mellon FA (2001) Rerouting the plant phenyl propanoid pathway by expression of a novel bacterial enoyl-coa hydratase/lyase enzyme function. Plant Cell 13:1669-1682.

McConn M and Browse J (1996) The critical requirement for linolenic acid is pollen development, not photosynthesis, in an arabidopsis mutant. Plant Cell 8:403-416.

Odell JT and Russell SH (1994) Use of site-specific recombination systems in plants. In: Paszkowski J (ed) Homologous Recombination and Gene Silencing in Plants. Kluwer Academic Publishers, The Netherlands, pp 219-270.

Ow DW and Medburry SL (1995) Genome manipulation through site-specific recombination. Crit Rev Plant Sci 14:239-261.

Phatak SC and Jaworski CA(1989) UGA 1-MS male sterile eggplant germplasm. Hort Sci 24:1050.

Phatak SC, Liu J, Jaworski CA and Sultanbawa AF (1991) Functional male sterility in eggplant: Inheritance and linkage to the purple fruit color gene. J Hered 82:81-83.

Que Q, Wang H and Jorgensen RA (1998) Distinct patterns of pigmentations suppression are produced by allelic sense and antisense chalcone synthase transgenes in petunia flowers. Plant J 13:401-409. 
Rosellini D, Pezzotti M and Veronesi F (2001) Characterization of transgenic male sterility in alfalfa. Euphytica 118:313319.

Russell SH, Hoopes JL and Odell JT (1992) Directed excision of a transgene from the plant genome. Mol Gen Genet 234:4959 .

Sauer B and Henderson N (1988) Site-specific DNA recombination in mammalian cells by the Cre recombinase of bacteriophage P1. Proc Natl Acad Sci USA 85:5166-70.

Song HY, Ding JG, Cao BH, Lei JJ and Song M (2004) Construction of the expression vectors for artifial male sterility gene and fertility restoring gene. J Southwest Agric Univ (Nat Sci) 3:249-253.

Srivastava V and Ow DW (2002) Biolistic mediated site-specific integration in rice. Mol Breed 4:345-349.

Srivastava V, Anderson OD and Ow DW (1999)Single-copy transgenic wheat generated through the resolution of complex intergration patterns. Proc Natl Acad Sci USA 96:11117-11121.

Sternberg N and Hamilton D (1981) Bacteriophage P1 sitespecific recombination. I. Recombination between loxP sites. J Mol Biol 150:467-86.
Sternberg N, Sauer B and Hoess R (1986) Bacteriophage P1 cre gene and its regulatory region evidence for multiple promoters and for regulation by DNA methylation. J Mol Biol 187:197-212.

Stintzi A and Browse J (2000) The Arabidopsis male-sterile mutant, opr3, lacks the 12-oxophytodienoic acid reductase required for jasmonate synthesis. Proc Natl Acad Sci USA 19:10625-10630.

Tian SB, Wang YQ, Liu FH, Luo ZG, Pi W, Chen YK and Liu JS (2004) Development of eggplant functional male sterile lines and its utilization. Proceedings of the $12^{\text {th }}$ Eucarpia Meeting on Genetics and Breeding of Capsicum and Eggplant, pp 91.

Wang Y, Chen B, Hu Y, Li J and Lin Z (2005) Inducible excision of selectable marker gene from transgenic plants by the Cre/lox site-specific recombination system. Transgenic Res 14:605-614.

Associate Editor: Márcio de Castro Silva Filho

License information: This is an open-access article distributed under the terms of the Creative Commons Attribution License, which permits unrestricted use, distribution, and reproduction in any medium, provided the original work is properly cited. 